\title{
SEASONAL VARIATIONS IN HOST-PARASITE RELATIONS BETWEEN FISH AND THEIR PROTOZOA
}

\author{
By ElMer R. NOBLE \\ University of California, Santa Barbara College
}

(Text-fig. I)

Most papers on the subject of parasitology have been confined to descriptions and lists of parasites and to clinical and economical considerations. Ecological studies are more subject to errors of interpretation, and they usually require more time to complete. For these reasons an ecological approach to the study of parasitology has not been popular, but through such an approach the parasitologist has an opportunity to extend the range of his contributions to an understanding of basic problems in biology.

The term 'parasite' generally implies injury to a host, but parasitologists usually assume the absence of injury when visible evidence of it is lacking. Physiological injury may well exist in a healthy-looking animal. Parasites such as Entamoeba histolytica are injurious only occasionally, and are normally commensal in their relationship to the host. For these reasons I shall employ the term 'parasite' in a broad sense to include all organisms which normally nourish themselves within or on the body of another organism without destroying the latter.

Only one year was at my disposal for the present study, but I felt that a regular and systematic examination of the Protozoa and their fish hosts during the seasons of that year should result in information of value. I wish to emphasize that this report is presented primarily to suggest an ecological approach, often neglected, to problems in parasitology. Any significant conclusions on seasonal variations should be based upon at least three full annual cycles. My results, therefore, can only serve as a basis for further studies. The work was done at the Laboratory of the Marine Biological Association of the United Kingdom, Plymouth, from 28 July 1955 to I June I956. I am exceedingly grateful to the Director of the Laboratory, Mr F. S. Russell, and his staff, who generously placed all necessary equipment and supplies at my disposal. Dr C. E. Lucas of the Marine Laboratory, Aberdeen, and $\mathrm{Mr}$ E. Ford of the Marine Station, Millport, were very helpful in supplying material from Scottish waters. I wish also to acknowledge receipt, from the National Science Foundation, Washington, of a research grant which made my trip to England possible. 


\section{METHODS}

My studies were restricted to the Protozoa because an adequate attention to these forms, especially to the living parasites, consumed all of the available time. The fish used were the Lemon Sole (Microstomus kitt), the Dragonette (Callionymus lyra) and the Whiting (Gadus merlangus). They were collected by means of an otter trawl within about ro miles of the port of Plymouth. The fish were brought immediately to the laboratory, and were alive when I started work on them, or they were so recently dead that the blood flowed freely when the heart was cut. If the blood did not flow freely the fish was discarded. Blood for smears was obtained from the heart immediately after incision by a razor blade. In $M$. kitt the incision was made anterior to the liver after the peritoneal cavity was opened; in G. merlangus it was made between the gills before the body was opened; and in C. lyra it was made ventrally through the body wall. Before each incision the area to be cut was wiped with absorbent paper in order to reduce the possibility of contamination.

Macroscopic examinations of the following organs of each fish were made: skin, fins, mouth, pharynx, gills, viscera, kidney and peritoneal cavity. I recorded the appearance of all unusually heavy infections of worms, and gill infections by the copepod Lernaea. Other copepods were very seldom observed. Leeches were never found on the fish or in the water of the containers in which the fish were brought to the laboratory.

Microscopic examinations of the blood, gall bladder and gut contents were made for each fish. Occasionally, examinations of the stomach contents, urinary bladder and other organs were also made. The gut and gall bladder contents were examined in the fresh condition immediately after collection so that living parasites, if present, were easily observed. Relatively few permanent, stained preparations from these organs were prepared. Schaudinn's or Susa's fluids with iron haematoxylin were usually employed. The blood smears were fixed for from 5 to Io min in methyl alcohol as soon as they were dry, then stained for from 30 to $60 \mathrm{~min}$ in Giemsa diluted with a phosphate buffer solution.

Abundant evidence from numerous workers indicates that although young fish may have a high percentage of parasitic infection, the intensity is low. Adult fish have the most parasites because of their intensive feeding habits during growing stages, including the feeding on intermediate hosts, and because of an accumulation of parasites (see Dubinin, 1936). For these reasons I generally selected the larger fish for study. No particular effort was made to separate males from females, but no differences in the degree or kind of infection between the sexes were noted. A maximum of fifteen fish (usually five of each species) was studied at one time because I found that more than this number required so much time to dissect and examine, that degeneration of host cells and death of the parasites (especially flagellates) reduced the chances of their detection in fresh preparations. 


\section{THE HOSTS}

Of the fish studied, Microstomus kitt and Callionymus lyra are bottom feeders, and both are to be found in the same localities. If parasites of one have a wide range of host tolerance, the other fish might be expected to be host to the same parasites. M. kitt feeds primarily on polychaete worms which are the predominant fauna in the mud frequented by the fish. C. lyra, on the other hand, feeds upon practically any bottom-dwelling animal of suitable size; e.g. small crustaceans, annelids, arthropods and molluscs. It has been well established that differences in feeding habits are related to differences in parasites, especially when intermediate hosts are involved.

The two species of fish mentioned above are widely separated taxonomically. Microstomus kitt is a flatfish belonging to the family Pleuronectidae. Callionymus lyra is a member of the family Callionymidae, and is of a more conventional fish shape, except that its mouth is ventrally placed. It is brilliantly coloured, and the sexes are strikingly different in their external features. The third species of fish, Gadus merlangus, belongs to the family Gadidae. It is an active predator, feeding chiefly upon smaller fish, with a greater vertical range of habitat than is characteristic of the other two species.

Dr G. A. Steven of the Plymouth Marine Laboratory has been keeping records of the numbers of fish of each species taken by otter trawl during the past several years at Plymouth. Although the records are incomplete, the chart shows that Callionymus lyra tends to be found in greater numbers during the warmer months, but that the other two species of fish do not fluctuate in any consistent manner throughout the year. The records are tabulated in Table I.

TABLE 1. NUMBER OF FISH PER HAUL OF ONE HOUR AT PLYMOUTH, ENGLAND

Figures show an average usually of three or four hauls. From the records of Dr G. A. Steven (unpublished).

\begin{tabular}{|c|c|c|c|c|c|c|c|c|c|c|c|c|c|}
\hline Callionymus & $\begin{array}{l}\text { Jan. } \\
20 I\end{array}$ & $\begin{array}{l}\text { Feb. } \\
\text { I6I }\end{array}$ & $\begin{array}{l}\text { Mar. } \\
185\end{array}$ & $\begin{array}{l}\text { Apr. } \\
169\end{array}$ & $\begin{array}{l}\text { May } \\
\text { I5I }\end{array}$ & $\begin{array}{l}\text { June } \\
370\end{array}$ & $\begin{array}{l}\text { July } \\
335\end{array}$ & $\begin{array}{l}\text { Aug. } \\
572\end{array}$ & $\begin{array}{c}\text { Sept. } \\
373\end{array}$ & $\begin{array}{l}\text { Oct. } \\
548\end{array}$ & $\begin{array}{l}\text { Nov. } \\
\text { 419 }\end{array}$ & $\begin{array}{l}\text { Dec. } \\
\text { 24I }\end{array}$ & \multirow{3}{*}{1953} \\
\hline $\begin{array}{l}\text { Gadus } \\
\text { merlangus }\end{array}$ & $>I$ & I & 28 & 87 & 45 & 204 & 286 & 67 & 5 & 2 & 0 & 0 & \\
\hline $\begin{array}{l}\text { Microstomus } \\
\text { kitt }\end{array}$ & 9 & 7 & Io & 8 & 5 & 7 & 3 & 6 & 8 & 3 & 0 & 6) & \\
\hline $\begin{array}{l}\text { C. lyra } \\
\text { G. merlangus }\end{array}$ & $\begin{array}{l}239 \\
>1\end{array}$ & $\begin{array}{l}4 \\
0\end{array}$ & $\begin{array}{r}42 \\
7\end{array}$ & $\begin{array}{r}236 \\
33\end{array}$ & $\begin{array}{l}\text { N.R.* } \\
\text { N.R. }\end{array}$ & $\begin{array}{l}\text { N.R. } \\
\text { N.R. }\end{array}$ & $\begin{array}{l}\text { N.R. } \\
\text { N.R. }\end{array}$ & $\begin{array}{l}\text { N.R. } \\
\text { N.R. }\end{array}$ & $\begin{array}{r}200 \\
9\end{array}$ & $\begin{array}{r}385 \\
37\end{array}$ & $\begin{array}{r}6 I I \\
0\end{array}$ & $\begin{array}{r}176 \\
\text { II }\end{array}$ & \multirow{2}{*}{195} \\
\hline M. kitt & 4 & IO & II & 9 & N.R. & N.R. & N.R. & N.R. & $\begin{array}{l}9 \\
6\end{array}$ & 2 & 4 & 8 & \\
\hline $\begin{array}{l}\text { C. lyra } \\
\text { G. merlangus }\end{array}$ & $\begin{array}{l}94 \\
20\end{array}$ & $\begin{array}{l}91 \\
63\end{array}$ & $\begin{array}{l}98 \\
85\end{array}$ & $\begin{array}{r}79 \\
168\end{array}$ & $\begin{array}{r}168 \\
27\end{array}$ & $\begin{array}{r}437 \\
20\end{array}$ & $\begin{array}{r}377 \\
7\end{array}$ & $\begin{array}{r}294 \\
13\end{array}$ & $\begin{array}{l}\text { N.R. } \\
\text { N.R. }\end{array}$ & $\begin{array}{r}57 \\
5\end{array}$ & $\begin{array}{r}82 \\
I\end{array}$ & $\begin{array}{r}105 \\
0\end{array}$ & \multirow{2}{*}{1955} \\
\hline M. kitt & 13 & 7 & 6 & $2 \mathrm{I}$ & 9 & I3 & 7 & 9 & N.R. & I & 2 & o) & \\
\hline $\begin{array}{l}\text { C. lyra } \\
\text { G. merlangus }\end{array}$ & 136 & N.R. & N.R. & 243 & 192 & 545 & - & - & - & - & - & -1 & \multirow{3}{*}{1956} \\
\hline $\begin{array}{l}\text { G. merlangus } \\
\text { M. kitt }\end{array}$ & $\begin{array}{l}7 \\
4\end{array}$ & $\begin{array}{l}\text { N.R. } \\
\text { N.R. }\end{array}$ & $\begin{array}{l}\text { N.R. } \\
\text { N.R. }\end{array}$ & 29 & $\begin{array}{l}8 \\
4\end{array}$ & $\begin{array}{l}27 \\
\text { II }\end{array}$ & 二 & - & - & 二 & $\overline{-}$ & 二 & \\
\hline & & & & 15 & & & & & & & & & \\
\hline
\end{tabular}



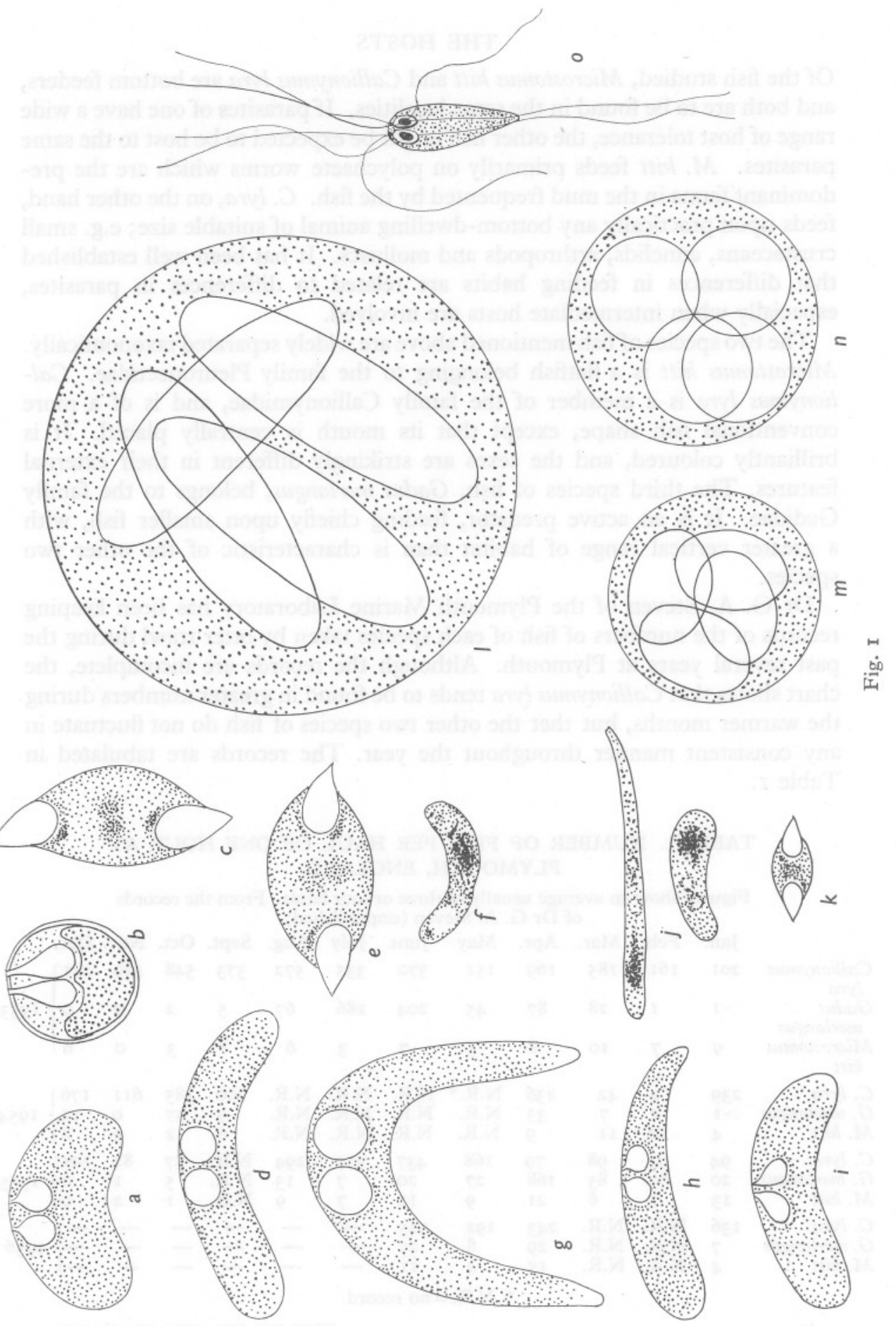


\section{THE PROTOZOAN FAUNA}

It is distressing to find statements in the literature indicating that a new species name has been created solely or even primarily because the parasite is found in a new species of host. Such a practice is entirely unwarranted. It is well known that many species of parasites have a wide range of host tolerance, and unless there are obviously-marked differences in morphology, and unless the entire life cycle is known, and sufficient numbers of individuals have been observed and measured, the description of a new species is unjustified. Too little attention has been paid to physiological differences which should be as important as morphological ones in the distinctions among species. Physiological characteristics are, of course, more difficult to identify, but this fact should not result in their being ignored. For these reasons I shall not attempt, at this time, descriptions or species designations of the forms which appear to be new. The figures illustrated in Fig. I are semi-diagrammatic to show only general form and relative sizes of the Protozoa which I have found. Lists of the Protozoa for each of the three fish are shown in Tables 2-4.

I have seen many forms intermediate in appearance between the two species of Callionymus-infecting haemogregarines described by Brumpt \& Lebailly, and I believe that only one species is present. Reichenow (I932) suggested that Haemogregarina callionymi is the sexual form of $H$. quadrigemina. H. binucleata was mentioned in I910 by Henry but he did not describe it. It also is probably $H$. quadrigemina. The two unspecified Ceratomyxa, one from the gall bladder, the other from the urinary bladder, and the Eimeria may be identical with species reported from other hosts, but, as indicated above, I shall not attempt a description of them at this time. Eimeria in the liver of Callionymus was frequently abundant enough to give it a speckled-white appearance. In such heavy infections the oocysts were usually found in large numbers in the gall bladder.

As regards the whiting, Auerbach (1910) distinguished Myxidium bergense from M. sphaericum Thélohan chiefly on the basis of the trophic stages which

\section{Legend to Fig. I}

Fig. I. Semi-diagrammatic drawings of Protozoa obtained from fish, intended only to show general outlines and relative size. Scale uniform. a, Leptotheca informis from gall bladder of Gadus merlangus. b, Myxobolus aeglefini from eye cartilage of Gadus merlangus. c, Myxidium sphaericum from gall bladder of Gadus merlangus. $d$, Ceratomyxa lata from gall bladder of Microstomus kitt. e, Myxidium sp. from gall bladder of Microstomus kitt. $f$, Haemogregarina platessae from blood of Microstomus kitt. g, Ceratomyxa sp. from urinary bladder of Callionymus lyra. $h$, Ceratomyxa sp. from gall bladder of Callionymus lyra. $i$, Ceratomyxa arcuata from gall bladder of Callionymus lyra and Gadus merlangus. $j$, Haemogregarina quadrigemina from blood of Callionymus lyra. $k$, Myxidium incurvatum from gall bladder of Callionymus lyra and Gadus merlangus. l, Eimeria sp. from gut of Gadus merlangus. m, Eimeria sp. from gut of Gadus merlangus. $n$, Eimeria sp. from liver of Callionymus lyra. o, Hexamita sp. from stomach and gut of Gadus merlangus. 
in the former species has medium-pointed pseudopodia and a length up to $54 \mu$, while in the latter it is rounded, about $20 \mu$ in diameter with lobed pseudopodia. My observations suggest that these are the same species because there is a great deal of variation in dimensions and appearance of the trophic stages, depending on temperature, freshness of the preparation, age of parasites, etc. I could find no evidence for two distinct kinds of Myxidium spores within the size ranges of $M$. bergense and M. sphaericum.

\section{TABLE 2. PROTOZOA IN CALLIONYMUS LYRA}

\section{Previously reported}

Blood

Haemogregarina quadrigemina

Brumpt \& Lebailly, 1904 (Europe)

Report from Plymouth by Henry, 1913

$H$. callionymi

Brumpt \& Lebailly, 1904 (Europe)

Report from Plymouth by Henry, I910

H. binucleata

Henry, 1910, from Plymouth

Trypanosoma callionymi

Brumpt \& Lebailly, 1904 (Europe)

Report from Plymouth by Henry, 1913

\section{Found during}

present study

H. quadrigemina

(Fig. $\mathrm{I} j$ )

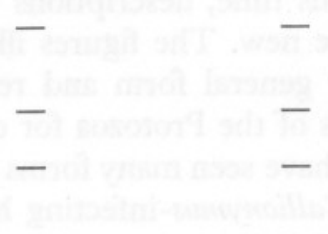

Gall bladder

Ceratomyxa arcuata

Thélohan, I892 (Europe)

Report from Plymouth by Dunkerley, I920

Myxidium incurvatum

Thélohan, 1892

Report from Plymouth by Dunkerley, r920

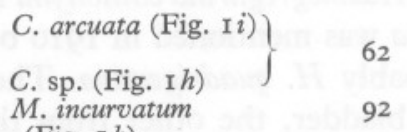

(Fig. I $k$ )

Liver

Urinary bladder

Muscle

Ceratomyxa sp.

(Fig. I $g$ )

(4 out of 8 )

Chloromyxum quadratum

Thélohan, I894 (Europe)

Nosema destruens

(Thélohan, I89r), Labbé, r899 (Europe)

The Eimeria of the gut of Gadus merlangus undoubtedly belong to two species because of the marked differences in shape and size of oocysts. Hexamita in the stomach and gut is very similar to several species which have been described from unrelated hosts (see Wenrich, I935). This genus is remarkable in its lack of host specificity, and I hope to make a special study of the form in Gadus merlangus, and relate it to the more general problem of host-specificity and origin of parasitism. Myxobolus aeglefini was found in only one out of the 200 fish examined. 
TABLE 3. PROTOZOA IN GADUS MERLANGUS

Previously reported

Found during present study

Percentage of hosts infected

\section{Gall bladder}

Ceratomyxa arcuata
Thélohan, I892 (Europe)
Report from Plymouth by
Leptotheca informis
Auerbach, I910 (Europe)
Myxidium bergense
Auerbach, I910 (Europe)
M. sphaericum
Thélohan, I894 (Europe)
Report from Plymouth by
Amyloodinium ocellatum
(Brown), I 934 (England)
Myxobolus aeglefini
Auerbach, I906 (Europe)
Mrázesia piscicola
Cépède, I924 (Europe)

C. $\operatorname{arcuata}$ (Fig. I $i$ )

2

L. informis (Fig. I a)

I7

M. incurvatum (Fig. I $k$ )

Thélohan, 1892

M. sphaericum (Fig. I c)

Gills

Bone and cartilage

M. aeglefini (Fig. $\mathrm{I} b$ )

0.5

Pyloric caecae

Stomach and intestine

\begin{tabular}{|c|c|c|}
\hline- & $\begin{array}{l}\text { Eimeria sp. no. } \mathrm{I} \text { in gut } \\
(\text { Fig. } \mathrm{x} l)\end{array}$ & 0.5 \\
\hline & $\begin{array}{l}\text { Eimeria sp. no. } 2 \text { in gut } \\
\text { (Fig. I } m \text { ) }\end{array}$ & I.5 \\
\hline & $\begin{array}{l}\text { Hexamita sp. in gut and } \\
\text { stomach (Fig. I } O \text { ) }\end{array}$ & 4 \\
\hline
\end{tabular}

TABLE 4. PROTOZOA IN MICROSTOMUS KITT

Previously reported

Found during present study

Percentage

of hosts

infected

\section{Blood}

Haemogregarina platessae

Lebailly, I904 (Europe)

H. platessae (Fig. If )

$\mathbf{I} \cdot \mathbf{I}$

Report from Plymouth by Henry, I9I3

H. flesi

Lebailly, I904 (Europe)

Ceratomyxa awerinzewi

Reichenow, I929 (Europe)

Ceratomyxa lata

Dunkerley, I920 (Plymouth)

\section{Gall bladder}

The Myxidium from Microstomus kitt appears very similar to M. bergense Auerbach originally described from Gadus virens. Ceratomyxa lata seems to have two forms (possibly two species), one with relatively large (average $5 \cdot 2 \mu$ in diameter) polar capsules, and the other with smaller (average $3.2 \mu$ ) polar capsules. The size of the spore $(9$ by $25.7 \mu)$ is somewhat larger than that 
originally reported by Dunkerley. Haemogregarina platessae and $H$. flesi seem to be identical (see Reichenow, 1932). Ten schizonts from my preparations of blood smears averaged $2 \cdot 4$ by $8.4 \mu$.

\section{SEASONAL VARIATIONS}

The intensity of infection was estimated on the basis of relative numbers of individual parasites as seen through the microscope, using an oil-immersion objective and Io $\times$ ocular. One to about fifteen parasites in a field was designated as + . If the field was crowded with parasites it was designated as +++ , and everything between these two was listed as ++ . The obvious limitations of this method did not prevent a reasonably accurate indication of shifts of infection intensity, but for definite and convincing results a more precise method would have to be used, and the results subjected to a statistical analysis. I arbitrarily divided the year into three periods roughly corresponding to summer, winter and spring. The times of my arrival in and departure from Plymouth prevented collections of fishes during the month of June and most of July. The results are listed in Tables 5-7.

Material from a small number of the same three species of fish collected at Millport and at Aberdeen during the month of October I955 indicated similar degrees of infection as those found at Plymouth during the same month.

\section{Callionymus lyra (Table 5)}

Some evidence for seasonal changes is to be found in this fish. Heavy infections of myxosporidia in the gall bladder occurred in $19 \%$ of the summer fish, and rose to $40 \%$ in winter fish. At the same time, however, and in the same fish, haemogregarines of the blood showed a reverse tendency. The blood in $24 \%$ of the fish was heavily infected during the summer, while only $7 \%$ were heavily infected during the winter.

TABLE 5. CALLIONYMUS LYRA, SEASONAL DATA

\begin{tabular}{|c|c|c|c|c|c|}
\hline & & & Percentage & ish infecte & \\
\hline & $\begin{array}{l}\text { Intensity } \\
\text { of infection }\end{array}$ & $\begin{array}{l}\text { Summer } \\
28 \text { July to } \\
3 \text { I Oct. } \\
76 \text { fish. }\end{array}$ & $\begin{array}{l}\text { Winter } \\
\text { I Nov. to } \\
29 \text { Feb. } \\
62 \text { fish }\end{array}$ & $\begin{array}{l}\text { Spring } \\
\text { I Mar. to } \\
26 \text { May } \\
62 \text { fish }\end{array}$ & $\begin{array}{l}\text { Total of } \\
200 \text { fish }\end{array}$ \\
\hline $\begin{array}{l}\text { Myxosporidia in } \\
\text { gall bladder }\end{array}$ & $\begin{array}{c}\overline{+} \\
++ \\
+++\end{array}$ & $\begin{array}{r}0 \\
39 \\
42 \\
19\end{array}$ & $\begin{array}{r}2 \\
14 \\
44 \\
40\end{array}$ & $\begin{array}{r}0 \\
27 \\
46 \\
27\end{array}$ & $\begin{array}{l}0.7 \\
27 \\
44 \\
28 \cdot 3\end{array}$ \\
\hline $\begin{array}{l}\text { Haemogregarines } \\
\text { in blood }\end{array}$ & $\begin{array}{c}- \\
+ \\
++\end{array}$ & $\begin{array}{l}36 \\
40 \\
24\end{array}$ & $\begin{array}{r}28 \\
66 \\
7\end{array}$ & $\begin{array}{l}35 \\
48 \\
17\end{array}$ & $\begin{array}{l}33 \\
51 \\
16\end{array}$ \\
\hline
\end{tabular}

Twice as many spring fish were infected with gill copepods (Lernaea) and internal worms as were the summer and winter fish. Liver infection with Eimeria occurred in one summer fish, four winter fish and thirteen spring 
fish. Worm infections were never heavy and no general correlations between the intensities of Protozoa and worms were noted in Callionymus lyra. The gall bladders of $99.3 \%$ of the fish contained myxosporidia, and $66 \%$ of these fish were infected with haemogregarines.

\section{Microstomus kitt (Table 6)}

There was a slight increase in numbers of winter fish with heavy gall bladder infections, but the small numbers involved preclude any generalization. Cysts of larval worms were occasionally found in the viscera. Of the total fish, over $99 \%$ were infected with myxosporidia.

TABLE 6. MICROSTOMUS KITT, SEASONAL DATA

Percentage of fish infected

\begin{tabular}{|c|c|c|c|c|c|}
\hline & $\begin{array}{l}\text { Intensity } \\
\text { of infection }\end{array}$ & $\begin{array}{l}\text { Summer } \\
28 \text { July to } \\
31 \text { Oct. } \\
70 \text { fish }\end{array}$ & $\begin{array}{l}\text { Winter } \\
\text { I Nov. to } \\
29 \text { Feb. } \\
5 \text { I fish }\end{array}$ & $\begin{array}{l}\text { Spring } \\
\text { I Mar. to } \\
26 \text { May } \\
55 \text { fish }\end{array}$ & $\begin{array}{l}\text { Total of } \\
\text { I } 76 \text { fish }\end{array}$ \\
\hline $\begin{array}{l}\text { Myxosporidia in } \\
\text { gall bladder }\end{array}$ & $\begin{array}{c}- \\
+ \\
++ \\
+++\end{array}$ & $\begin{array}{r}3 \\
93 \\
4 \\
0\end{array}$ & $\begin{array}{r}0 \\
53 \\
33 \\
14\end{array}$ & $\begin{array}{r}0 \\
62 \\
33 \\
5\end{array}$ & $\begin{array}{r}\text { I } \\
69 \\
24 \\
6\end{array}$ \\
\hline
\end{tabular}

Gadus merlangus (Table 7)

No seasonal changes are indicated. Heavy worm infections (predominantly nematodes) appeared to be more abundant during the spring period. Of the total fish, $79 \%$ were infected with myxosporidia.

TABLE 7. GADUS MERLANGUS, SEASONAL DATA

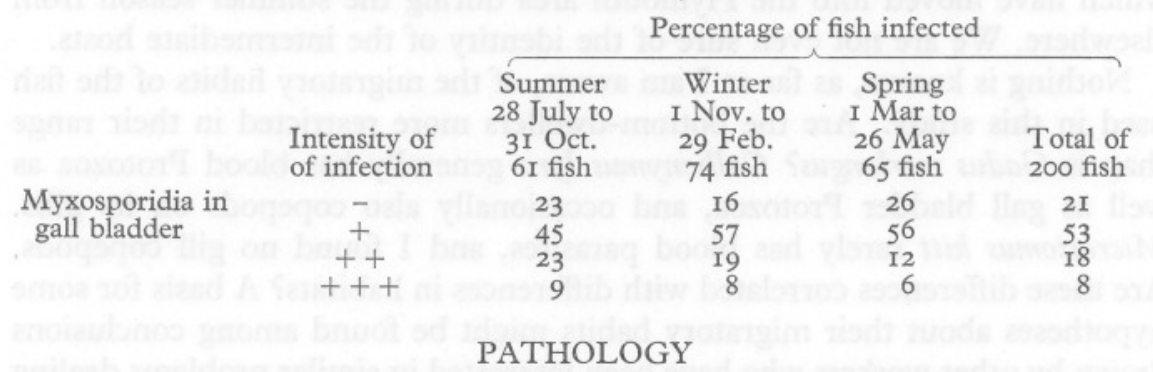

Protozoan parasites, in general, appear to be of a commensal nature in fishes, but very little work has been done on the effects of parasites on the growth and development of these hosts. The most commonly infected organ in all the fish examined was the gall bladder, containing myxosporidian parasites. Infected bile undergoes chemical changes as indicated by a yellow colour and changes in density and viscosity. In a heavily infected gall bladder the bile often becomes so viscous that it does not flow when the shrunken bladder is cut open. Its contents are frequently of a white, cheese-like consistency. Similar pathological changes, however, may appear when there is no visible 
evidence of the presence of myxosporidia or of bacteria, and the pathological changes are presumably due, in these instances, to a virus infection.

The only other infected organs found to exhibit visible signs of pathology were the eyes of one specimen of Gadus merlangus, the cornea and sclera of which were spotted by opaque, white cysts of the myxosporidian, Myxobolus aeglefini; and the liver of Callionymus lyra which was occasionally speckled with cysts of Eimeria. One observation not indicated in the previous tabulations of results, and often noted by parasitologists, was the apparent deleterious effect on one species of parasite by the presence of unusual numbers of another species of parasite in the same host body. For example, during massive infections of nematode worms, Protozoa were greatly reduced in numbers, or they were absent.

\section{DISCUSSION}

If one may assume that myxosporidia are consistently abundant in the gall bladders of Callionymus lyra in summer, and that haemogregarines are consistently more abundant in the blood in winter (an assumption based on little evidence), one might correlate these changes with population fluctuations of the hosts (see Table I). One might assume that the Plymouth area during the summer months is more favourable for intermediate hosts of haemogregarines and less favourable for infection with myxosporidian spores than during the winter months. But we do not know whether the fish that are caught during the summer months are those that are left behind when most of the population migrates to places unknown, or whether they represent fish which have moved into the Plymouth area during the summer season from elsewhere. We are not even sure of the identity of the intermediate hosts.

Nothing is known, as far as I am aware, of the migratory habits of the fish used in this study. Are the bottom-dwellers more restricted in their range than is Gadus merlangus? Callionymus lyra generally has blood Protozoa as well as gall bladder Protozoa, and occasionally also copepods on its gills. Microstomus kitt rarely has blood parasites, and I found no gill copepods. Are these differences correlated with differences in habitats? A basis for some hypotheses about their migratory habits might be found among conclusions drawn by other workers who have been interested in similar problems dealing with freshwater fish. Bychowskaja (1936), for example, found that fish in small lakes have fewer numbers and kinds of parasites than do fish in large lakes. It occurred to me that perhaps marine fish in a restricted habitat have fewer parasites than marine fish which roam over a wide area. Unfortunately, few studies have been made on migrations of marine fishes, and, while bottomdwelling fish might be expected to be the more restricted in their range, I know of no proof for the assumption. One might predict, however, on the basis of their respective parasitic faunas, that $C$. lyra has a wider migratory range than has $M$. kitt. Gorbunova (1936) studied the variations of the 
parasites of freshwater pike and roach with respect to their ages. She found that, in addition to an increase in numbers of parasitic species with the ages of the hosts, the fauna in fish of quieter habits is poorer than that in the predatory fish (i.e. pike). Again applying these findings to my own studies, one could correlate the relatively poorer protozoan fauna exhibited by $M$. kitt with the presumably more restricted and 'quieter' bottom habitat which the host occupies.

Gadus merlangus has a diet restricted chiefly to small fish, but there appeared to be more varieties of fish in its stomach than varieties of annelids in the stomach of Microstomus kitt. In addition, G. merlangus probably has a wider migratory range than has $M$. kitt. These factors would suggest a higher degree of parasitism in G. merlangus, and my records show that ten species of Protozoa have been reported from this fish as compared with four species from $M$. kitt. In addition, G. merlangus is much more heavily infected with worms than is either Callionymus lyra or M. kitt. C. lyra, on the other hand, consumes a wide variety of food, and it has demonstrated a marked seasonal fluctuation in population numbers. It has about the same numbers of kinds of protozoan parasites as has G. merlangus, but the percentage of hosts infected with Protozoa is considerably higher.

It is surprising that my search for blood parasites in 200 stained slides, each from a different Callionymus lyra, did not reveal a single trypanosome. The fact that in I9Io Henry found, at Plymouth, six out of fifteen of these fish to be infected with trypanosomes suggests that they are subject to a yearly fluctuation of trypanosome infection. The fluctuation may be due to a periodic disappearance of leeches which serve as intermediate hosts, but haemogregarines are also transmitted by leeches, and haemogregarines were common in C. lyra, and occasionally they were found in Microstomus kitt. In fact, the abundance of haemogregarines in C. lyra, with the absence of leeches, throws doubt on the assumption that these parasites in this fish are transmitted by leeches. A few copepods attached to the gills were examined for haemogregarines but the results were negative.

The results of my studies, together with those of other writers, suggest the following tentative conclusions. An active predatory habit predisposes to heavy parasitism, but this result may be off-set by a restriction of the diet to one or to a few kinds of food species. Likewise, a less active host may acquire numerous kinds of parasites because of a taste for a wide variety of foods. A sluggish bottom-feeder with little tendency toward migration, and with limited tastes for food variety, tends to acquire relatively few kinds and numbers of parasites.

I have raised more questions than I have answered, but these questions suggest several lines of research which should be of significance in the field of ecological parasitology. Mere descriptions of parasites and their life cycles (including those which I have previously authored) generally carry with them 
implications of completeness which can be grossly misleading. Such descriptions fail to impress the reader with the impact of environmental changes, both internal and external, upon host-parasite relationships.

\section{SUMMARY}

From July I955 to June I956 a study of host-parasite relations between three species of marine fish and their Protozoa was made at Plymouth. Callionymus lyra, a bottom-dweller, tends to be more abundant during the summer months, consumes a wide variety of food, and was more heavily infected with Protozoa than were the other two species of fish. Gadus merlangus is an active predator, feeding on small fish, and although it has about the same numbers of kinds of Protozoa as does C. lyra, it was less heavily parasitized. G. merlangus, however, was more heavily parasitized with worms than were the other two fish. Microstomus kitt is a sluggish bottom-dweller, feeding on annelids, and, although over $99 \%$ were infected with myxosporidia, the intensity of infection was generally low. Very few other parasites were found in M. kitt.

An active predatory habit combined with a taste for a wide variety of food appears to predispose to heavy parasitism. Some evidence for seasonal variations in intensities of protozoan infection in Callionymus lyra was obtained, but for conclusive results more precise methods of measuring numbers of parasites, and further studies carried on over a period of at least three consecutive years, must be made. The report is presented primarily to emphasize the importance of an ecological approach to the study of parasitology.

\section{REFERENCES}

Auerbach, M., 1906. Ein Myxobolus im Kopf von Gadus aeglefinus L. Zool. Anz., Bd. 30 , pp. $568-70$.

- I9I0. Biologische und morphologische Bemerkungen über Myxosporidien. Zool. Anz., Bd. 35, pp. 57-63.

BRown, ElEANOR M., 1934. On Oodinium ocellatum Brown, a parasitic dinoflagellate causing epidemic diseases in marine fish. Proc. zool. Soc. Lond., pp. 583-607.

BRUMPT, E. \& Lebailly, C., 1904. Description de quelques nouvelles espèces de Trypanosomes et d'Hémogrégarines parasites des Téléostéens marins. C.R.Acad. Sci., Paris, T. 139, pp. 613-15.

BychowsKaja, I., I936. The influence of the dimensions of the waterbasins on the parasitic fauna of fish. In V. A. Dogiel's 'Problems of ecological parasitology'. Ann. Leningrad State Univ., No. 7, pp. 163-6. (In Russian.)

CÉPÈDE, C., I924. Mrázekia piscicola n.sp. microsporidie parasite du merlan Gadus merlangus Linné. Bull. Soc. zool. Fr., T. 49, pp. 109-13.

DuBININ, V. B., 1936. Investigation of the parasitic fauna of Thymallus vulgaris in various periods of its life. In V. A. Dogiel's 'Problems of ecological parasitology'. Ann. Leningrad State Univ., No. 7, pp. 31-48. (In Russian.)

Dunkerley, J. S., 1920. Fish Myxosporidia from Plymouth. Parasitology, Vol. I2, pp. $328-33$. 
GorbunOVA, M., 1936. Variations of the parasitic fauna of the pike and the roach with their age. In V. A. Dogiel's 'Problems of ecological parasitology'. Ann. Leningrad State Univ., No. 7, pp. 5-30. (In Russian.)

HenRY, H., I9Io. On the haemoprotozoa of British sea-fish (a preliminary note). F. Path. Bact., Vol. I4, pp. 463-5.

Henry, H., 1913. A list of blood parasites of sea-fish taken at Plymouth. F. mar. biol. Ass. U.K., Vol. 9, pp. 570-I.

LABBÉ, A., I899. Sporozoa. Das Tierreich, Bd. 5, I80 pp.

Lebailly, C., I904. Sur quelques hémoflagellés des téléostéens marins. C.R. Acad. Sci. Paris, T. 139, pp. 576-7.

Reichenow, E., I929. Sporozoa, Ciliata und Suctoria. In Doflein, F. \& Reichenow, E., Lehrbuch der Protozoenkunde (Aufl. 5), Teil 2.

- 1932. Sporozoa. Tierwelt N.- u. Ostsee, Teil 2, g, pp. I-88 (Lief. 21).

ThÉlohan, P., I89I. Sur deux sporozoaires nouveaux, parasites des muscles des poissons. C.R. Acad. Sci. Paris, T. I12, pp. I68-7I.

1892. Sur quelques coccidies nouvelles parasites des poissons. F. Anat., Paris, T. 28, pp. I5I-7I.

— I894. Recherches sur les myxosporidies. Bull. sci. Fr. Belg., T. 26, pp. 100-394.

WeNRICH, D. H., 1935. Host-parasite relations between parasitic Protozoa and their hosts. Proc. Amer. phil. Soc., Vol. 75, pp. 605-50. 